DOI: $\underline{10.52950 / S S .2021 .10 .1 .003 ~}$

\title{
OPERATION STORM: ENDING HUMANITARIAN DISASTER AND GENOCIDE IN SOUTHEASTERN EUROPE
}

\author{
DOROTHY S. MCCLELLAN, NIKOLA KNEZ
}

\begin{abstract}
:
Operation Storm was the single-most decisive battle of the Croatian War for Independence (1991-1995). Launched by the Republic of Croatia in August 1995, it was the largest European land battle since the Second World War. Outnumbered, outgunned, but not outmaneuvered, this tiny new democracy prevailed in a David versus Goliath encounter, a moral as well as military victory. Storm ended a massive humanitarian disaster and genocide. It led to the liberation of one third of Croatian territory, and made possible the Dayton Agreement that brought peace to the region. Based on interviews conducted with the American Ambassador to Croatia during the war years, military and political principals in the battle, noted scholars, security and intelligence agency officials, humanitarian leaders and journalists, this social scientific qualitative study examines the political and historical origins of the war and its aftermath. The article documents the events leading up to the war and surrounding this extraordinary military operation, providing strategic and political insights into the need for cooperation between democratic allies.
\end{abstract}

\section{Keywords:}

war, humanitarian disaster, genocide, Yugoslavia, Croatian War for Independence, Balkans, democracy, human rights, rights, Greater Serbia, Ambassador Peter Galbraith, Hague Tribunal, Operation Storm

JEL Classification: D74, K33, K42

\section{Authors:}

DOROTHY S. MCCLELLAN, Texas A\&M University-Corpus Christi, United States, Email: dorothy.mcclellan@tamucc.edu NIKOLA KNEZ, President of ifilms, Director of Croatian Film Institute, President 21st Century Society for Human Rights \& Education, United States, Email: nikola@ifilms-fx.com

\section{Citation:}

DOROTHY S. MCCLELLAN, NIKOLA KNEZ (2021). Operation Storm: Ending Humanitarian Disaster and Genocide in Southeastern Europe. International Journal of Social Sciences, Vol. X(1), pp. 39-73., 10.52950/SS.2021.10.1.003 
In an age of universal deceit, telling the truth is a revolutionary act.

George Orwell

\section{Introduction}

At the twenty-fifth anniversary of the end of the brutal war in the former Yugoslavia (1991-1995), there is good reason to evaluate lessons learned, as well as continuing challenges to democratic nation building in Southeastern Europe. People around the globe recall a war that shocked the conscience of the modern world by its deliberate carnage, primitivism, and countless atrocities. President Bill Clinton once remarked that bringing Serbia to its knees was a precondition for getting them to the peace table and bringing an end to the conflict (Cohen 1996, p. 32). Operation Storm, the largest European land battle since the Second World War (Riley 2010, p. 216), launched by the Republic of Croatia in August 1995, fulfilled that requirement. The singlemost decisive battle of the Croatian War for Independence, Operation Storm ended the massive humanitarian disaster and genocide committed by the Serbian Army and Chetnik terrorists. It led to the liberation of one third of Croatian territory seized by the enemy, and made possible the Dayton Agreement that brought peace to the region (CIA 2002, pp. 374-377).

The success of this remarkable military action by Croatia came after four years of brutal fighting. Outnumbered, outgunned, but not outmaneuvered, this tiny new democracy prevailed in a David versus Goliath battle, a moral as well as military victory by an exceptional people. Operation Storm provides strategic and political insights into the need for cooperation between democratic allies. Through interviews with diplomatic, political, military, intelligence and security experts, as well as historians, scholars, and principals in Operation Storm, this article documents the key factors surrounding this pivotal battle against long-standing Serbian oppression and aggression.

As Peter Galbraith, U.S. Ambassador to Croatia during the war years 1993-1995 points out in interview, the U.S. deeply appreciated Croatia's "willingness to spend treasure and blood to end the humanitarian disaster," thereby making possible the Dayton Agreement that brought peace to Southeastern Europe. Galbraith continues: Dayton "was, however, never intended as a roadmap for the organization of a country. It was intended as a means of ending a war and bringing peace to the region..." (April 4, 2019). This article recognizes that twenty-five years after the signing of the Dayton Agreement, a roadmap for the region still needs to be drawn up. Let the process begin here.

\section{The Broad Goals of the Project}

While in Croatia as a Fulbright scholar 2002-2004 and 2012, Dr. Dorothy McClellan, Regents Professor of Criminal Justice at Texas A\&M University-Corpus Christi, undertook a multi-faceted, international collaborative project with filmmaker Nikola Knez, Chair of the Board of Directors of the Croatian Film Institute, President of the Croatian Society for Human Rights, and President of iFilms LLC, to examine challenges to democratic nation building in this post-conflict society. Over the course of the Fulbright fellowships and beyond, the focus of our work has been on the post- 
WWII forced repatriation and subsequent murder of Croatians in Yugoslavia, as well as the Croatian War for Independence 1991-1995 and its aftermath.

The overarching goals of this article are:

To document Croatia's historical struggle to create an independent, democratic state in response to the challenges posed by the driving ideology of "Greater Serbia".

To examine Operation Storm's decisive role in ending the recent war in the Balkans.

To draw attention to the unresolved issues that mitigate against a full democratic future for the region.

To seek international foreign policy support for minimizing Russian influence in the region and strengthening ties to trusted democratic allies in light of increasing instability in the Western Balkans.

To demonstrate the power of a just cause to successfully confront and defeat evil.

This article aims to set the record straight concerning the actual events leading up to the battle that turned the tide of history, and to articulate and postulate possible outcomes of a decadeslong struggle to throw off the yoke of Serbian hegemony.

\section{Historical, Political \& Ideological Roots of the Struggle}

For centuries Croatia had sought unsuccessfully to realize its destiny as a fully independent nation embodying the fundamental principles of freedom, liberty, and the pursuit of happiness. At the end of the First World War and with it the end of the Habsburg Empire, Croatia faced brutal and intensely political, economic and cultural subjugation at the hands of Serbia (Ramet 2006, pp. 36-38). Repeated attempts by the Croatian political leadership to seek true reconciliation with neighboring states fell victim to Serbia's lust for expansion and openly professed ideology of Greater Serbia (Ramet 2006, pp. 38-40). Sources document that as early as 1917 brutal policies and practices were sanctioned, financed, and imposed on the Croatian people by the Serbian government in Belgrade. These include the assassination of Croatian political leaders, the plundering of villages, and the murder of dissenting intellectuals and civilians with the intention of annihilating the Croatian people and their rich culture.

The "Greater Serbia" imperialist ideology manifested itself under the Kingdom of Serbs, Croats and Slovenes (1918-1929) (see excerpts from Jovan Cvijić in Beljo 1998; Ramet 2006, pp. 36-38) and later under the unilaterally proclaimed dictatorship of the Kingdom of Yugoslavia (1929-1941) (Ramet 2006, pp. 130-153). Both of these regimes, controlled by the Serbian Karadjordjević monarchy, forcefully promoted the imperialist genocidal document Nachertanije, an ideological 
memorandum that insisted on annihilation of Croatians as an imperative to Serbian territorial expansion (Ilija Garasanin, Nacertanije, 1844, in Beljo 1998; Ramet 2006, pp. 32-40).

The list of Croatian grievances was long and touched on all aspects of civil and political life-economics, politics, education, culture, and human rights (Šulyak 1977, pp. 110-132). Historical evidence abounds demonstrating that Serbian policies promoted:

- The dissolution of the centuries-old Croatian Parliament and the abolition of municipalities, provinces, schools, and judicial systems (Šulyak 1977, pp. 106-111; Radić in Vukmanić 1995 a, b, c, d).

- The arbitrary and capricious military imposition of taxes (Šulyak 1977, pp. 112-113, pp. 116-132; Radić in Vukmanić 1995 a, b, c, d).

- The nationalization of state properties including forests, mines, public buildings and monetary fund (Radić in Vukmanić 1995 a, b, c, d).

- The systemic denial of Croatian language and the arrogant theft of Croatian culture (see Vuk Karadzić, Serbs All and Everywhere, 1849, in Beljo 1998).

- Sanctioned and financed Serbian paramilitary terrorism on Croatian soil (see Nikola Stojanović's 1902 To Extermination: Ours or Yours? in Beljo 1998; Šulyak 1977, pp. 105106).

- Violations of human rights, denial of free speech, due process, assembly, and suffrage (Šulyak 1977, pp. 110-115; Radić in Vukmanić 1995 a, b, c, d).

During the period from 1918-1941, Croatian political leaders at home and emigres abroad filed countless petitions and memoranda intended to inform influential governments of the grave situation, to no avail (Šulyak 1977, pp. 72-96, pp. 116-200). The grievances were heard and ignored, requests for assistance and intervention were marginally considered and tabled. The Croatian people were left to suffer the indignities and brutal institutional and state oppression alone. The lack of morality of the leading European nations was notorious and manifested itself in illegal treaties and denials of oppression at major international forums (Šulyak 1977, pp. 135186). In May 1919, Stjepan Radić filed a petition seeking an end to Serbian oppression and the violation of human rights with the Paris Peace Conference. It included 150,000 signatures along with a note indicating that an additional 450,000 signatures had been illegally seized by the Karadjordjević government. The grievances were ignored, requests for assistance and intervention marginally considered and tabled.

On June 20,1928, a mass assassination attack on Croatian deputies in the Belgrade Parliament was carried out by Serbian Deputy Punisa Racić. He killed three prominent Croatian politicians-visionary democrats Stjepan Radić, Pavle Radić, and Djuro Basarice--and wounded two Croatian deputies--Ivan Pernar and Ivan Grandja. Stjepan Radić was a political leader and thinker whose speeches and scholarship fill four volumes (see Vukmanić, Miroslav 1995, a.b.c.d.). Serbian King Alexander was widely held responsible for supporting the assassinations (Croatian Viewpoint 2008; London Times 1928 (1) p. 1, and (2) p. 17; Kulundžić 1967, p. 22; Šulyak 1977, pp. 49-51, pp. 109-110). Having brutally removed the opposition, on January 6, 1929 he proclaimed a dictatorship and changed the country's name to Yugoslavia (which translates as Southern Slav). 
After a decade of state-sponsored criminal abuse, this was considered a formal negation of Croatian national identity (Šulyak 1977, pp. 34-51).

On February 16, 1931, Croatian historian and politician Milan Šufflay was ambushed and brutally murdered by members of the Yugoslav regime's organization, Young Yugoslavia, a group financed and protected by Serbian King Alexander. Yugoslav state-sponsored intimidation of the civilian population and the murder of dissenting intellectuals was commonplace and ongoing. Albert Einstein and Heinrich Mann in a letter to the International League of Human Rights in Paris (Ligue des droits de l'homme) condemned the murder of Dr. Šufflay to the global cultural community. Their letter appealing for protection of Croatian scientists from the Yugoslav regime appeared on the front page of The New York Times on May 6, 1931, directly accusing Serbian King Alexander of complicity in the crime (Cohen and Riesman 1996, pp. 10-11).

During World War II, Zagreb was the capital of the Independent State of Croatia. In the historical period of the Second World War, the fate of Croatia lay in the uncertainties of the terrifying political and military drama that was unfolding. Those were complex times. One could argue that no other nation drawn into World War II experienced as many conflicts of competing interests within the confines of its borders as did the tiny nation of Croatia, that beautiful piece of real estate nestled along the Adriatic Coast.

In the spring of 1941 , Croatia was invaded by Germany from the North and Italy from the South. Germany bombed and occupied Belgrade on April 6, 1941 (Redzić 2005, p. 9; Tomasevich 1975, p. 55). Serbia surrendered on April 17 (Ramet 2006, pp. 138-140). The Serbian royal family fled to London (National Archives, RG 84). The Yugoslav army in Serbia simply disintegrated. On April 10, 1941, John James Meily, the American consul in Zagreb, reported on the events as they happened: "At noon, the head of the Croatian cabinet informed the U.S. Consulate in Zagreb that Croatia had formally seceded from Yugoslavia. Yugoslavia, until then comprised of Croatia, Serbia and Slovenia, had been dominated by a Serbian dictatorship, which Croatia now formally rejected" (Šulyak 1977, pp. 168-170).

On April 10, 1941 Colonel Slavko Kvaternik proclaimed the birth of the Independent State of Croatia in the name of Dr. Ante Pavelić, exiled revolutionary leader of the Croatian "Uprisers" (Ustashe). In 1934 Pavelić had organized the assassination of King Alexander in Marseille. In response to Serbian oppression, young attorney Pavelić had launched the Croatian Home Guard newspaper and established the Uprisers organization with the aim of breaking up Yugoslavia and establishing an Independent State of Croatia (Muzić 1991, pp. 26-28).

The 1941 proclamation for the Independent State of Croatia was received by the Croatian people with enthusiasm and was seen as a victory after 23 years of Serbian genocidal policies (see Stevan Moljević, Homogeneous Serbia, 1941, in Beljo 1998). Pavelić returned to Croatia on April 14, 1941, four days after the proclamation of Croatian independence. He capitalized on the nation's hunger for freedom and utilized world conflict to define his role in history. While initially considered an accomplished revolutionary and patriot by his followers, in the end he was widely condemned for his ultra-nationalism, for implementing racial laws against Serbians and Jews 
(Glenny 2001, p. 318; Tomasevich 1975, p. 10; Tomasevich 2001, p. 32), in short, for his policy of appeasement toward Germany, that left Croatia a puppet state of the Third Reich (Banac 1988, p. 4; Deutschland Military Tribunal 1950, pp. 1302-03; Frucht 2005, p. 429; Graubard 1993, p. 153).

If Germany was surprised by Croatia's proclamation of independence, Italy was furious. Mussolini wanted no independent Croatia. He had the grandiose dream of restoring the ancient glory of the Roman Empire by seizing all of Croatia's territory. Twelve Italian divisions, 200,000 Italian troops of the 2nd Italian Army, marched into Croatia through Slovenia and the Adriatic coast (Bosworth 2005, pp. 112-13; Rodogno 2006, p. 95). That prompted immediate diplomatic negotiations between Croatia's new government and the Italians, which led to the Pact of Rome that relinquished to Italy part of the Dalmatian Coast (Thomas \& Mikulan 1995, p. 10). The signing of the Pact resulted in a temporary alleviation of tensions, but paved the way to a longterm tragedy for the Croatian nation. In short: Croatia wanted its independence. Italy wanted Croatia to become its colony. Germany accepted Croatian independence with the expectation that Croatia would be incorporated into the domain of the Reich to counteract Italian expansion (Pavlowitch 2008, p. 15). In the 19th century, Croatian politician and writer Ante Starčević said: "Croatians want to be free from subjugation, not to exchange one subjugation for another" (Starčević 1999, p. 15). However, in the whirlpool of world conflicts, that is precisely what happened.

The Serbian state and their terrorist Chetniks, an extreme right-wing nationalist guerrilla force, launched attacks on the unfortified frontier of the newly formed Independent State of Croatia. The Chetniks and Serbs joined with Tito's communist Partisans with the intention of making the Croatian nation pay dearly for destroying their dream of a Greater Serbia (Tomasevich 1975, p. 226; Roberts 1973, p. 26; Ramet 2006, pp. 145-155). Croatia's thirteen hundred-year old dream of independence was shattered. Attacked from the north, south, and east, the country became a killing ground (Tomasevich 2001, p. 60).

In 1945, just a few days after the end of World War II, Tito and his communist Partisans in Yugoslavia initiated an extermination campaign against men, women, and children they viewed as enemies of the regime. The mass slaughter began with the forced repatriation of approximately 700,000 Croatian and Slovenia civilians and soldiers who fled to Austria seeking asylum immediately at the close of the war to escape the victorious communists (GrahekRavančić 2006, p. 32; Jareb and Omrčanin 1977-1978, p. 51). The refugees were deceived into believing they were being sent to the American safe zone in Italy. Instead, they were loaded onto trains and sent back to Yugoslavia (Tolstoy 1986, pp. 11, 111-112, 394-395; Prcela and Zivić 2001, p. 306, 390-394; McClellan and Knez 2018, pp. 65-73). Large numbers were massacred outright upon their return, others died on forced death marches and in mass executions across the country (Prcela and Guldescu 1995, pp. 370-379; Tolstoy 1986, pp. 198-200; Tolstoy 1979, p. 360; Epstein 1973; Geiger 2013, pp. 77-80; Willoughby in Prcela and Guldescu 1995, pp. 125535; Pinter 2018; see also Beljo 1985 and 1995).

The Socialist Federal Republic of Yugoslavia established by Tito after World War II was comprised of six republics and two autonomous regions: The Socialist Republic of Croatia, Serbia, Slovenia, Bosnia and Herzegovina, Montenegro, Macedonia, and the autonomous 
regions of Vojvodina and Kosovo. However, under the 1974 Constitution, Yugoslavia became a federal union with confederative characteristics. This gave each of the republics the right to secession or separation from the federation.

With the collapse of the Berlin Wall in 1989, the agent states of the Soviet Union sought their independent, separate destinies, and self-determination. The countries of Eastern Europe made a relatively peaceful transition to independence. But in the case of the Socialist Federal Republic of Yugoslavia, that was not so. Serbian nationalism and fascism began to strengthen. The Serbians held supremacy in the military and political decision-making process and were determined to resist independence movements.

The Communist Party of Croatia in February 1990 passed an election law on multi-party elections, enabling the people to have a pluralist democracy. In 1991, the people of Croatia expressed their will in a referendum that overwhelmingly favored $(93.5 \%)$ their political independence and separation from Yugoslavia. Shortly thereafter Slovenia, Bosnia and Herzegovina and Macedonia followed suit. The belligerent reaction of the Serbian political and military establishment against Croatia for aiming to establish a sovereign country was swift and brutal. They tried to occupy the whole of Croatia.

Serbian ideology, reflected in the 1986 Memorandum of the Serbian Academy of Science and Arts (see Serbian Academy of Arts and Sciences Memorandum 1986 in Beljo 1998), promoted the concept of Serbian racial superiority that would later reemerge in a campaign of ethnic cleansing that took the form of genocide, rape and sexual enslavement by the Serbians. The Memorandum sowed the seeds of Serbian hegemony and aggression by promoting the idea that Serbs were victims, although in fact they were the majority population and held supremacy in the military and political decision-making process. In self-pitying prose reminiscent of Mein Kampf, and with belligerent intent, the Memorandum advocated radical political action, giving rise to a new political movement (see Memorandum in Beljo 1998). The Serbian media played a key role in promoting the false narrative of Serb endangerment that led to the justification for Serbian aggression. The Serbians were determined to resist independence movements. The fact that the capital city of the Socialist Federal Republic of Yugoslavia was Belgrade contributed to the Serbian sense of dominance over the other republics.

As Peter Galbraith, United States Ambassador to Croatia 1993-1998, succinctly puts it for the first time, twenty-five years after the war began:

I think it is important as we look back at the Croatian War, I would call it the Croatian War of Independence 1991-1995, to see this as a war, first a war for independence, but as a war of self-defense. Croatia was attacked by the JNA, the Yugoslav Army, and the rebel Serbs who controlled thirty percent of Croatia's territory in the Krajina and in Eastern Slavonia, who were supported, paid for, and put in position by what had become a foreign country, namely Serbia (in interview, April 4, 2019). 


\section{Methodology}

In the tradition of qualitative social science research (Alasuutari 2010, pp. 139-155), and employing an oral history methodology (Charlton et al. 2007), we collaborated with Dr. Miroslav Medjimorec to carry out interviews with Croatian and Bosnian military and political principals in the Croatian War for Independence, filming them in the summer of 2013. We asked these individuals to describe their wartime experiences, and to offer their most significant insights into the events surrounding Operation Storm and what it represented to the final outcome of the war. In addition, we arranged filmed interviews with noted historians, scholars, intelligence and security agency officials, humanitarian leaders and journalists whose professional experience provides political and historical analysis of the war and its aftermath. Each of the interviews lasted from two-three hours. Most were conducted on site in Croatia, several in Bosnia and Herzegovina. In April 2019, the authors conducted a lengthy interview with former U.S. Ambassador to Croatia Peter Galbraith at the Army and Navy Club and Library in Washington, D.C. who served as Ambassador from 1993-1998. He spent several hours before arriving for our meeting preparing for the interview by reviewing his diplomatic diaries and personal and professional papers held in the archives of the Library of the National Defense University at Fort Lesley J. McNair, Washington, D.C. The precision, clarity, and detail of his comments in this ninety-minute filmed interview are exceptional. Excerpts of all of the above-mentioned interviews are included in this article.

Documentary film is now integral to academic pedagogy and a powerful tool to reach broad audiences, so a major aspect of this study was to produce a documentary film about Operation Storm that relies on those interviews. The film, Operation Storm, was completed in September 2019. Since the interviews were conducted in multiple languages (Croatian, Bosnian, English), we undertook the production of both an English language and Croatian language version of the documentary to reach out to an international audience. Our cast for the English language voiceovers was drawn from twelve highly respected American lawyers, public officials, and professionals. The documentary received two Silver Remi Awards from WorldFest International Film Festival Houston in April 2020, one for film production, the other for the screenplay.

The documentary film Operation Storm was the centerpiece of a Capitol Hill, Washington, D.C. event "Croatia's Role in Southeastern Europe -- Growing Instability in the Region" on October 24, 2019, co-sponsored by the Croatian Congressional Caucus, the Croatian Embassy, and the National Federation of Croatian Americans. The Fulbright Association invited the authors to give a presentation entitled "Operation Storm: Ending Humanitarian Disaster \& Genocide in Southeastern Europe" at the 42nd Anniversary of the Fulbright Association Conference in Washington, D.C. on October 25, 2019. The film premiered on October 27, 2019 in Manhattan, New York at the Tavelić Center. Operation Storm received more than 157,000 views in the first two months after it was posted on YouTube in August 2020. 


\section{Operation Storm and its Aftermath}

According to General Atif Dudaković, Commander, Fifth Corps of the Army of Bosnia and Herzegovina (ARBIH),

As early as 1990, there were bloody terrorist acts. Serbs in Croatia put up barricades on public roads, blocked traffic, and ambushed a bus filled with Croatian police officers, killing them all. The first Serbian terrorists were led by so-called Captain Dragan, a Serb with an Australian passport. Who were these people? It is well known that the provocateurs were led by Belgrade, in particular, the people gathered around Milosević and his political idea of Greater Serbia.

As Miroslav Tudjman, Director of the Croatian Intelligence Agency 1993-2000, currently Member of the Croatian Parliament, and son of former Croatian President Franjo Tudjman, explains:

The origin of the war in Yugoslavia is rooted in the idea of a Greater Serbia. Serbs considered Yugoslavia as only a transitional phase of political development in the creation of a Greater Serbian country, and that all other people living there were only transitory social groups without rights to an independent country of their own.

The Socialist Federal Republic of Yugoslavia was an artificial political creation. Stretching across an extensive area of Central and Southeastern Europe, Yugoslavia's 22 million inhabitants fought on opposite sides in the Second World War, carried enormous resentments toward one another, practiced different religions, yet were forced to co-exist.

Dr. Ante Nazor explains:

Yugoslavia rested on three pillars. The first was the authority of Josip Broz Tito as lifelong president. The second was the League of Communists of Yugoslavia, a monolithic party that did not allow for democracy or a multi-party, political system. The third was the secret police and the Yugoslav People's Army (in interview August 2013).

Dudaković recalls:

In the 1990s I was a major in the Yugoslav Army ... When I analyze the causes of the war, I recall Serbian rallies, the appearance of the Chetniks under the leadership of Seselj, the Serbian demonstrations in Kosovo, Montenegro, and Vojvodina... They called for Serbians to arm themselves. I was wondering against whom would they wage war? Why would they wage war? The world must know that the aggression was started by Serbia (in interview August 2013). 
By 1991, it was visible that the British, French and Russians gave the Serbians the political green light to transform the Socialist Federal Republic of Yugoslavia into Yugoslavia. In June of 1991, Secretary of State James Baker visited Belgrade and assured the political establishment that the U.S. was committed to the "territorial integrity of Yugoslavia" (Cohen 1992; Bethlehem and Weller 1997, xxvii; Cohen in Meštrović 1996, p. 38). He warned the Slovenes and Croatians that "a cold welcome awaited any action toward independence or secession" (Cohen 1992; Cohen in Meštrović 1996, p. 38).

Despite Baker's warning, in 1991 the people of Croatia expressed their will in a referendum which favored overwhelmingly their political independence. On June 25, 1991, the Croatian Congress declared Croatia's independence and separation from Yugoslavia. Shortly thereafter Slovenia, Bosnia and Herzegovina, and Macedonia followed suit. The belligerent reaction of the Serbian political and military establishment against Croatia for aiming to establish a sovereign country was swift and brutal. In July 1991, the Armed Forces of Serbia and Montenegro along with the Chetniks, an extreme right-wing nationalist guerrilla force, viciously attacked the Republic of Croatia, attempting to occupy the whole of it (Armatta 2010, pp. 160-165, p. 196; Hoare 2010, p.111-136).

As Tudjman explains in interview,

On 25 June 1991, Croatia and Slovenia proclaimed their independence. Under pressure from the international community, the implementation of this decision was postponed for three months. Exactly 3 months later, on 25 September 1991, the U.N. called on member states to implement an embargo on the import of weapons to Slovenia and Croatia. This was proposed by the Yugoslav Ambassador to the U.N., Budimir Lonchar. This political move by the U.N. gave the green light to the Yugoslav People's Army and Serbia to use force against those democratic republics that advocated independence and autonomy, all with the intention of preserving Yugoslavia as an artificial creation of the communist regime. That decision triggered the war in the former Yugoslavia. Political responsibility is borne by the international community.

In interview, General Dudaković recalls

Suddenly, fighting began on the territory of Croatia. Several Croatian villages were attacked by Serbs, which the daily Yugoslav newspaper described as 'cleaning' operations. There is no military term such as 'cleaning.' Rather, we use terms such as 'attacking,' 'defending,' and 'occupying.' Thus, it becomes obvious that they were referring to ethnic cleansing of the domestic Croatian population by Serbian terrorists and Chetniks. Roads were blocked, the integrity of Croatia was violated, and the Croatian state was practically paralyzed. 


\section{Parliamentarian Tudjman states}

The war in the former Yugoslavia was started by the Yugoslav People's Army under the political leadership of Slobodan Milošević. The war was organized, supported and conducted from Belgrade, the capital of the Republic of Serbia. The attack on defenseless Vukovar and Dubrovnik on the territory of the Republic of Croatia began with an operation called "RAM". This military operation had two basic front lines of action. Their goal was to cut the Republic of Croatia in two.

The newly formed Republic of Croatia did not have an army, nor were Croatian citizens permitted to legally own weapons to defend their lives and country. The U.N.-imposed arms embargo on the export of weapons had the effect of leaving the unarmed Croatian, Muslim, and Kosovo population at the mercy of the well-armed Serbian aggressor. This 4th largest army in Europe, unimpeded by international objections, was able to conquer territory, terrify civilian populations, and commit vicious crimes including genocide.

According to Historian Nazor:

At the beginning of the war, NATO alliance officials predicted that, if attacked, Croatia would be forced to surrender within two weeks. Thanks to the courage, loyalty and dedication of the Croatian soldiers, our country was successfully defended under these extremely unfavorable circumstances. 1991 was a critical year for our defense and for the creation of the modern Republic of Croatia. The final months of 1991 saw the fiercest fighting of the war, culminating in the Battle of the Military Garrisons, the Siege of Dubrovnik, and the Battle of Vukovar. The Serbs initiated a campaign of ethnic cleansing against Croatian civilians and most non-Serbs were either killed or expelled from occupied territory by early 1993.

Dr. Slobodan Lang, Humanitarian Advisor to Croatian President Tudjman 1993-2000 recalls:

I went to see Kissinger and asked him to take steps to prevent Serbian aggression against Croatia. He told me, "Doctor, you are naive. Europe is not about to prevent this war. You do not have any allies. Your only hope is to develop the ability to defend yourselves."

Croatia was forced to defend itself on multiple fronts. It faced exceptionally critical situations from Slavonia to the Dalmatian coast. The defense of the city of Vukovar is symbolic of Croatia's response to aggression. Serbia attacked the city of Vukovar with a force of 80,000 soldiers, 1,600 tanks and armored personnel carriers, 980 artillery weapons, 350 anti-aircraft guns with 750 rocket launchers. The defense of the city was mounted by 1,850 lightly armed Croatian volunteers. Over the course of the 87-day siege, Vukovar was ripped from the heart of Croatia. This was an heroic struggle, often compared to the Battle of Stalingrad. Dr. Edward Slavko Yambrušić, international lawyer, fellow of the Center for the Research of International Law and International Relations of the Hague Academy writes: 
Clearly, it was a legal, legitimate response to Serbian aggression, an act of self-defense that is an inherent, inalienable right, an individual and collective right of states to respond to aggression, as provided for by Article 51 of the U.N. Charter. Indeed, according to Chapter 7 of the U.N. Charter, a defending state is an active participant with the U.N. Security Council in a joint legal enterprise to stop aggression and restore peace and security (in interview April 4, 2019; see also Yambrušić 2010, pp. 20-25).

It was here that the young Croatian state established its reputation for courage and determination in the face of the overwhelming enemy force. When Vukovar was totally destroyed, the Serb occupier entered the town and committed mass genocide against Croatian civilians. In response to that horror, Croatia created an army capable of halting Serbian aggression. Serb units suffered huge losses and were unable to advance further into Croatian territory.

According to Ambassador Galbraith,

Enormous crimes were committed against Croats and in Croatia, notably the eighty-seven day siege of Vukovar, the systematic destruction of the city, and then the murder of the patients at the Vukovar hospital who were then dumped in a mass grave at Ovćara, the ethnic cleansing of the Croats in the Krajina region, the shelling of Zagreb which I witnessed, the shells landed close to my office. There were many, many crimes committed against Croatia (in interview April 4, 2019).

Tudjman explains:

When the Serbian leadership and the Yugoslav People's Army realized that they could not advance further into Croatian territory as they had planned, they agreed to a ceasefire. The Croatian leadership, due to the great losses they had sustained and their lack of material technical resources, also had an interest in a ceasefire. This resulted in the signing of the Sarajevo Agreement for the deployment of U.N. peacekeepers. The Cyrus Vance plan was signed on 2 January 1992. Croatia made the most of this pause in the fighting to establish a professional army to protect against further losses in subsequent warfare.

Croatia accepted the Vance Plan permitting the deployment of a 10,000-strong United Nations Protection Force on Croatian territory that had been occupied by the Serbs. UNPROFOR was established in February 1992 as an interim arrangement to create the conditions of peace and security required for the negotiation of an overall settlement of the Yugoslavian crisis. The role of the U.N. troops was to ensure that territory designated as "U.N. Protected Areas" became and remained demilitarized and that all persons residing in these areas were protected from fear of armed attack. The role of U.N. police monitors was to ensure that local police forces carried out their duties without discriminating against persons of any nationality or abusing any human rights (Armatta 2010, pp. 194-196). 
Despite the U.N. protected zones and the Sarajevo and Vance Agreements, the Serbian military mounted brutal attacks on Croatia. Tudjman states:

All of 1993 was marked by intense attacks by the Serbian army from Benkovac, Knin and Obrovac along the southern Croatian coast. This prevented all normal traffic along the Adriatic Highway, leaving open only a sea route to supply the civilian populations in Dubrovnik and other coastal towns and islands. It took a year before Operation Maslenica reopened the land route. The Serbs had destroyed the main bridge. So, Croatia built a pontoon bridge and undertook the construction of a permanent bridge.

General Rajko Rakić, Chief of Staff for General Ante Gotovina's Split Corps, smiles proudly as he says:

I didn't know General Gotovina until his arrival as a new commander of the operations zone for the district of Split. He seemed young, energetic and unworried. We saw before us a young man with new ideas. In taking command from his predecessor, he said: "I came to liberate Knin and I know how to do it." It was the one statement we least expected, but most desired. I wondered then, how does this commander plan to liberate Knin?

On 21 January 1993, Chief of the General Staff, General Janko Bobetko, appeared at the Croatian command headquarters. He reviewed all plans, and said: "I will determine exactly when this military operation will begin." General Rakić continues:

Over the next 4 or 5 days of the offensive operations, the Croatian army liberated the outskirts of Zadar, the territory near Obrovac, and the Zemunik air base. They enabled de-mining operations to proceed, and liberated the village of Skabrnja where Serbs had massacred the entire civilian population.

Western countries, led by the British, were not inclined to permit the pontoon bridge to be put into service for use by UNPROFOR. They even threatened sanctions through the Security Council, but General Gotovina was persistent. He called the commander of UNPROFOR and personally took him across the bridge. It was filmed by Croatian television crews. Gotovina announced: "If the Commander of UNPROFOR can cross the bridge, all of his troops heading south toward Dubrovnik and Bosnia and Herzegovina should also be permitted to use it." And from that moment forward, UNPROFOR used the pontoon bridge.

Tudjman explains that the relationship between the U.S. and Croatia changed and developed over the course of the war:

The official cooperation between Croatia and the United States occurred at two levels-militarily and politically. The relationship between the military and intelligence services was excellent. America helped in the training and formation of the Croatian Army. American 
drones were used to collect data. Cooperation at the political level was more complex because of the internal conflicts in the NATO alliance and the contrary interests of some of the European Union countries. By 1994, the U.S. increasingly understood the situation in Croatia and Bosnia and Herzegovina, and offered great political support to Croatia, recognizing that Croatia had pursued a policy of adhering to international law. President Tudjman met on at least eight occasions with U.S. President Bill Clinton (in interview August 2013).

Historian Mate Kovacević reminds us:

British and French diplomatic policy supported the survival of Yugoslavia as a single state or as a set of Serbian states that would emerge out of the occupied parts of Croatia and Bosnia and Herzegovina (in interview September 2013).

Tudjman in his interview states:

After three years of UNPROFOR's mandate, nothing had been accomplished. The Republic of Croatia decided to end the mission. In a conversation between President Tudjman and U.S. Vice President AI Gore in Copenhagen, it was agreed that U.N. forces would leave Croatian territory. This resolution was an indication of the good relations between America and Croatia.

General Rakić in his interview reports:

In November 1994, Chief of Staff General Janko Bobetko held a meeting in Split which lasted all day. The General was a very thorough, conscientious commander, interested in every detail of Operation Maslenica. He wanted the situation on the front from Velebit to Dinara to remain stable. He sought precise information on military strategy and resources, as well as the time line for the operation.

Due to harsh winter conditions and frigid temperatures, Croatian soldiers could not remain on Mount Dinara for an extended period of time. Units of the 4th Guards Brigade, the 114th Brigade, and the Auxiliary 6th Homeland Regiment arrived at pre-arranged intervals that allowed for no more than three to five day stays. A few elite troops had attempted to stay longer. But they died from exposure. They perished in place.

General Rakić in his interview confirms:

We also had to build wooden houses that were transported by Croatian Army helicopters to Mount Dinara so that the soldiers had shelter that would enable them to endure the conditions. Throughout the war on the Dinara and Livansko Delta, there was a positive rivalry between brigades of the Croatian Army. They competed with each other over who 
could liberate the most occupied territory. General Gotovina, generally speaking, always took advantage of pre-emptive capability.

Helicopter units from the Zemunik Air Base played a key role in all of the fighting around Mount Dinara. Helicopters flew until midnight, picking up wounded soldiers from the combat zone and transporting supplies.

General Rakić explains:

Without their support, this would have been an impossible task. Before this, the Croatian Air Force had never performed such a mission. The courage and heroism of these pilots deserves recognition and great praise.

The Winter 1994 military operation began amidst a great blizzard during which it was difficult to determine the elevation in the deltas. The storm lasted for eight days. The operation did not begin in a classical way, with a frontal attack. Instead units of Croatian special forces were inserted behind the enemy lines. The Croatians mounted their attack from the rear. Thus, the Croatians launched the attack using diversionary tactics and then hit from multiple directions. Hit-and-run to the next target surprised the enemy and enabled the Croatians to win a solid victory. It took nearly eight months of hard fighting to liberate the area, since it was swamp land.

\section{U.S. Ambassador Galbraith reports in his interview:}

I was asked if I would fly down to a summit which was taking place between Izetbegović and Tudjman along with their top officials in Split. It was a very critical meeting. They worked out agreements on joint military actions in Bosnia. I was not involved in any of those negotiations directly, but I did talk to Miomir Zuzul who was at this point the Croatian Ambassador to the United States, and a close advisor to Tudjman. And I had suggested to him that the joint declaration include the following language, that "Bosnia Herzegovina requests the assistance of Croatia in the defense of Bosnia." And, why was that language important? Because it would justify as a matter of international law Croatia's direct military involvement in Bosnia. Because under international law, of course, you cannot go into the territory of another state unless you are invited. And this was an invitation, and it was an invitation based on the inherent right of self-defense in the U.N. Charter. So that was in the declaration. What was looming ahead was the thing that could bring the war in Bosnia to an end and save Bihać. There were 160,000 people there, at least 40,000 of whom were men and boys at risk of being massacred.

Victorious military Operation "Flash" in Western Slavonia destroyed the entire corps of the Serbian Army. This victory greatly improved the morale of Croatian soldiers at Mount Dinara. 
General Rakić in interview states:

After each lost battle, the Serbian army carried out various reprisals against Croatian civilians in Knin, Banja Luka and other places throughout Bosnia and Herzegovina. There were many instances of destruction of churches. In the village of Presnac, the Serbs killed a Catholic priest and a nun. As a result of that, Bishop Komarica went on a hunger strike to protest the atrocities. All of the victories of the Croatian army made possible the Split Declaration. It seemed that nothing could be done without the Croatian army. When I speak of General Gotovina, I must say that he engaged in military operations with his whole being, with his spirit, with his heart. He was indeed a true commander who lived among his soldiers.

In the midst of the Croatian military successes, the President of Bosnia and Herzegovina, Alia Izetbegović, sent a congratulatory message to President Tudjman with an invitation to liberate Sarajevo which was under siege by the Serbian army.

According to Galbraith in his April 2019 interview:

There was growing concern that the Serb plan was to divide Sarajevo, basically cut the inner city off from the airport. This led to NATO airstrikes and the Serbs responded by taking U.N. Peacekeepers as hostages, actually chaining some of them to places that might be bombed. I mean it was a total crime under international law. But the effect of that was to make the U.N. reluctant to authorize NATO airstrikes and NATO reluctant to undertake them. In fact, there was a secret deal between the U.N. General and the Serbs that there wouldn't be bombing and the Serbs then took that as a green light to clean up the map of Bosnia and to "take" the safe areas.

According to historian Kovacević in his interview:

After the signing of the Split Agreement between Tudjman and Izetbegović, a British elite troop unit suddenly appeared in the area around Tomislavgrad in Herzegovina. It was their intention to occupy the area around Mount Dinara in order to stop the advance of Croatian combat troops heading toward Knin. Fortunately, the British were forced to leave the area. We all thought, "Nice try."

Historian Nazor in interview describes the critical situation as follows:

Serbian aggression against Bosnia and Herzegovina was heavily underway. Bosnia and Herzegovina's forces were incapable of mounting a successful defense. Had Croatia's military not come to their aid, all of Bosnia and Herzegovina would have been occupied by the Serb army. 
"The human losses were enormous," says Jakob Bienenfeld, President of Bet Israel Congregation of Croatia.

The war between the Muslims and the Serbs was harsh. I believe that between 250,000 and 300,000 people died. The war was primitive and bloody. But Croatia responded by offering sanctuary to Jews and Muslims.

Historian Nazor continues:

At this time of Serbian aggression against Bosnia and Herzegovina, Croatia became a refuge for at least 200,000 Muslims whose lives were saved by Croatians, when they were forced to flee their own country ahead of the Serb troops. The Croatian state took them in. And this is also a significant component of the role Croatia played in the defense of Bosnia and Herzegovina.

Mr. Bienenfeld explains:

I was selected by the Council of Jewish community members to rescue the besieged Jewish people from Sarajevo. We should not forget that the greatest assistance in these efforts came directly from Croatian Minister of Defense Gojko Šušak, General Praljak, and the Croatian Army. This was a war in which Croatian Jews suffered alongside Croatian people as a result of Serbian aggression. The Jewish community in Croatia was placed under the protection of the entire Croatian political leadership by President Franjo Tudjman and Defense Minister Gojko Šušak. Throughout the war, Croatian people showed great concern for the Jewish people, which is evident from the fact that the Croatian state offered all Jews from Bosnia and Herzegovina Croatian citizenship. This meant that every one of us who came to Croatia was welcomed. This gave our Jewish community great faith in the Croatian state. Croatia in this war can be very proud of its treatment of the Jewish people.

Bienenfeld alludes to the period of World War II when, under Ante Pavelić's rule, the NDH adopted racial laws that discriminated against Jews and resulted in their arrest, murder or deportation.

Dr. Sc. Dinko Ćutura, historian and director of the Croatian State Archives, describes the U.N.'s initial response to the massive human tragedy:

In 1993, the U.N. Security Council established six security zones in Bosnia and Herzegovina. These were the areas of Sarajevo, Srebrenica, Žepče, Tuzla, Gorazde and Bihać. In Bosnia and Herzegovina, the international forces were required to commit themselves to establishing peace with their army and then guaranteeing the security and stability of the area. However, that did not happen. Instead, what occurred was massive genocide in Srebrenica in 1995 (in interview, September 2013). 
The U.N. protected area of Srebrenica was penetrated by the Yugoslav People's Army, the Serbian Army, and Chetniks who committed genocide against the Muslim population. More than 8,000 people were killed in two days of slaughtering. Tadeusz Mazowiecki, the U.N. Special Rapporteur on Human Rights said:

Due to the events in Bosnia and Herzegovina in the past few weeks, and especially the fact that the United Nations has allowed the fall of Srebrenica and Žepa, along with the terrible tragedy that has struck the people in these "safe areas", which were guaranteed by international agreements, I feel obliged to declare that I no longer see the possibility to continue to act as a special correspondent at this time. Some countries, including the United Kingdom, concealed and destroyed evidence of the Serbian massacre of the people in Srebrenica (Mazowiecki 1995; Osser \& de Saint-Exupery 1995).

According to Galbraith in interview, "There is no doubt that the evidence of what had happened in Srebrenica changed the thinking in Washington".

Miomir Zuzul, Croatian Ambassador to the United Nations 1993-1996, explains:

The fall of Srebrenica demonstrated the complete helplessness of the international community. The deplorable crime of genocide by Serbs who killed over 8,000 inhabitants in two days was the worst crime in Europe after the Second World War (in interview September 2013).

Galbraith continues:

But Mladić, being Mladić, really a criminal, sadistic, cruel individual, wasn't just content with taking Srebrenica.

Richard Holbrooke, Assistant Secretary of State for European and Eurasian Affairs 1994-1996, reminds us:

There were other Serbian atrocities in that terrible month of July 1995. Serbs attacked the Muslim enclave of Bihać. Washington was still uncertain of what to do next. Croatia and its leadership recognized that only powerful military action could force the Serbs to withdraw their military and sit down at the peace table (Holbrooke 1999, p. 32).

Bihać had been under siege by Serbian military forces for two-and-a-half years. Although Bihać was one of five security zones under the protection of the United Nations, its 160,000 residents, refugees and displaced persons were exposed to armed attacks, starvation, poisoning attempts, and threats of genocide. It was widely recognized that the danger of genocide on an even larger scale than Srebrenica was likely. 
Mario Bujanović, member of the Croatian Defense Council in Bosnia and Herzegovina, city of Bihac, reports:

The town of Bihać was surrounded by Serb forces. The first days were difficult and uncertain. There were many wounded. Bihać was on the edge of survival. The city of Bihać was successfully defended in the Serb siege because it received great help from Croatia. Food, medicines, and weapons were regularly delivered by the Croatian Air Force (in interview August 2013).

Marijan Mihić, also a member of the Croatian Defense Council in Bosnia and Herzegovina, interviewed on location in Bihać, reported that

The main stronghold of the Serbs around Bihać was at the Grabska Garrison from which the city was bombarded every day, and suffered great devastation. We are standing on the front line of the city of Bihać, which was defended by members of the 2nd Croatian Squad along a 42-kilometer front. To the right of us is the city water supply which was destroyed by the Serbs. The city of Bihać was without water (in interview August 2013).

Dr. Roman Jurić, also a member of the Croatian Defense Council described the situation:

Living and surviving 1201 days encircled and under siege is a difficult life experience that the citizens of Bihać endured during the homeland and liberation war. This experience involved daily shelling, killing, fear for life and limb, loss of loved ones, hunger, suffering, destruction of body and soul (in interview August 2013).

Ante Marijanović states:

Who knows what the fate of Bihać and the surrounding cities would have been--Velika Kladusa, Buzim, Cazin and Bosanska Krupa--had we not been rescued by the Croatian state and the Croatian army. There would probably have been a humanitarian catastrophe with countless victims (in interview August 2013).

Bernardo Jurlina, Croatian Minister of Minister of Labor, Social Welfare and Family during the war states:

The city of Bihać was successfully defended in the Serb siege because it received great help from Croatia. Food, medicines, and weapons were regularly delivered by the Croatian Air Force (in interview August 2013). 
According to Emdzad Galijasević, Mayor of the city of Bihać,

At the time of Serbian aggression against Bosnia and Herzegovina, the aid coming from Croatia was of crucial importance for the survival of Bihać and Tzazin. As Mayor of the city of Bihać I would like to thank President Tudjman and the Croatian Ministry of Defense for their support, without which the citizens in this area and city could not have survived the siege (in interview August 2013).

Dr. Ćutura explains that

The territory of Bihać and Tzazin was defended by the 5th Corps of the Army of Bosnia and Herzegovina and by the Croatian Defense Council. The Serbs fiercely attacked the area and kept it completely encircled. The Croatian Defense Council successfully held a 40-kilometer front line against the Serbian attacker.

As Ambassador Galbraith states:

Even worse would be a situation where the Bosnian Serbs and the Croatian Serbs take Bihać. And what are they going to do if they do that? If they do the same thing that they did in Srebrenica, we are going to see 40,000 men and boys murdered.

General Kresimir Ćosić, Deputy Minister of Defense adds:

In 1994, U.S. Ambassador to the United Nations Madeleine Albright warned the U.N. Security Council and the entire world that the town of Bihać was under siege by Serbia. We must be grateful to her for her bravery in exposing the situation of civilians who were living under disastrous human conditions (in interview September 2013).

General Dudaković explains:

I sent urgent appeals for help to political and military authorities in Zagreb and begged them to understand that the situation we faced in Bihać was urgent and extremely serious. I explained that radical measures needed to be taken to rescue the population of the city and surrounding area.

NATO carried out an air attack on the Serbian airbase Udbina. The head of UNPROFOR, British General Rose, was opposed to the total destruction of Udbina. He warned the Serbs before the NATO attack, giving the Serbs time to remove aircraft from the air field. Just a few hours after the NATO attack, the base was back in operation and the Serbs continued their air strikes against the Croatian population. General Rose was opposed to strengthening the NATO attacks on the Serbs. In response to the attacks, the Serbs closed all of the checkpoints to civilian traffic, stopped flights to the Sarajevo airport, captured French, Canadian and Ukrainian soldiers who 
became hostages, and used them as human shields to deter future possible NATO air raids (see ABC Peter Jennings Special, The Peacekeepers: How the U.N. Failed in Bosnia, 1995).

Historian Kovacević confirms:

It is well known that in several instances British and French pilots promptly informed the Serbs about their pre-emptive strikes. Moreover, they dropped their bomb loads in the Adriatic Sea, not on the designated targets. Only American pilots performed their assigned missions properly. One American pilot was shot down and captured by the Serbs, but he was rescued and saved thanks to Croatian Special Forces.

Miroslav Tudjman explains:

To understand the situation in Bosnia and Herzegovina, it is essential to point out a disagreement between the world's major powers. There was an active conflict between the U.S. and other NATO members concerning military intervention in Bosnia and Herzegovina. Americans advocated military intervention, while other members of the NATO alliance were opposed to it.

Dr. Davor Marijan confirms Tudjman's position:

The international community was not prepared for military action. It was already resigned to the fall of Bihać and accepting the Serbian occupation of $80 \%$ of the territory of Bosnia and Herzegovina.

Tudjman reports:

Lord Owen, Chairman of the Contact Group that moderated the crisis, spoke to Croatian and Bosnian representatives. He stated: "Don't expect to gain through diplomacy what you haven't been able to achieve militarily."

General Rakić recalls:

General Gotovina came to my office and said: "Rajko, prepare a map for me. Make a plan to take the Croatian military force towards Glamoc." I looked at him and told him: "General I can do that, but I'm a professional soldier and I have never seen a single military operation in the history of warfare attack an enemy with our own forces divided--one part of the army going west, the other east. General Gotovina responded: "Just draw it, Rajko. It will be fine." I replied: "General, if that will work, you will be inducted into the History of Warfare Hall of Fame." And he was! 
President Franjo Tudjman and Alija Izetbegović signed a declaration for the implementation of the Treaty of Washington. The most important part of their meeting was an agreement on their military cooperation. Based on this agreement the Croatian forces launched Operation Summer 1995. The aim of the operation was to break the power of the Serbian army and Chetniks in the area of Livno, win Grahovo and Glamoć, and stop the Serbian attacks in the Bihać safe zone. With Operation Summer 1995, the conditions for the second military phase were created. The second phase would be Operation Storm.

Dr. Ivo Lucić, historian and former Chief of the Croatian Security Information Service states:

The moment that the Croatian army was victorious at Mt. Dinara in the hinterland of Knin it became clear to the Serbs that they could no longer hold the town of Knin under occupation. Under the circumstances, Milosevic ordered the Serb leaders in Knin to prepare for a retreat from Knin and to take with them the entire Serbian population (in interview September 2013).

According to a CIA Report: "The army of the Republic of Croatia in 1995 was not the same army as it had been in 1991. It used the four years of its existence to create a professional army of 75,000 members classified into eight brigades with a broad component of another 140,000 members of the National Guard" (CIA 2002).

\section{General Rakić recalls:}

General Gotovina came to a meeting on Brijuni and placed a map in front of President Tudjman and the generals. The meeting was one of heated debate over whether there was sufficient power to liberate Knin. Gotovina was confident that his units were ready because they had been successfully waging war on the battlefield for eight months and winning every battle. Gotovina told President Tudjman: "My soldiers cannot wait any longer. They see Knin in front of them. We are ready to attack, but we need your command to do so. President Tudjman stood beside Gotovina, placed his hand on the map and said, "Here it is. All of you do as Gotovina recommends."

Ambassador Galbraith explains:

I got a message, the message I wanted, which was to tell Tudjman that the United States effectively did not object. And I went down and saw him in Brijuni. My message was that we appreciate your willingness to spend treasure and blood to relieve the siege at Bihać. We want to warn you that if things don't go well, don't ask us to help you out. You're going to be on your own and it included, as I had recommended, important warnings that you had to protect the civilian population, be concerned about human rights, and make sure you don't harm the U.N. personnel. Of course, Tudjman understood this very clearly. Although I said, "This is not a green light." He said, "Yes, yes, it's not a green light." But, of course, it WAS a green light, and I knew it, and people in Washington knew it. 
President Tudjman's position was clear. The Croatian Army was not going to quietly stand by as the Serbs and Chetniks engaged in aggression against Bosnia and Herzegovina, while UNPROFOR turned their backs. The international community had the responsibility to prevent the escalation of conflicts, a new tragedy, and more refugees. Croatia was at that time providing safe haven to 600,000 refugees from Bosnia and Herzegovina.

Ambassador Galbraith describes what happened:

On July 21st I went down to Brijuni at the invitation of President Tudjman to join him for dinner with President Sami Süleyman Gündoğdu Demirel of Turkey. At the end of the dinner, Defense Minister Gojko Šušak pulled me aside to say that President Tudjman had decided on military action through Krajina to relieve the siege of Bihać.

On 4 August 1995 the Croatian Army began Operation Storm, a large-scale military offensive in areas occupied by the Serbs (Marijan 2010, pp. 76-77). Operation Storm was set out in four separate parts, designated Storm 1 through 4, which were allocated to various corps based upon their individual areas of responsibility (Marijan 2010, pp. 51-115). Croatia launched its 130,000 strong army (Thomas 2006, p. 55). Each plan was scheduled to take between four and five days.

Lieutenant General Ante Gotovina was assigned the Storm 4 plan, which was the primary component of Operation Storm. It included Mount Dinara, the toughest territory from which to engage the enemy. The 30,000-strong Split Corps was under Gotovina's command. The 3,100strong special forces deployed to the Velebit Mountain was commanded by Lieutenant General Mladen Markać. The 25,000-strong Croatian Army Gospić Corps, assigned the Storm 3 component of the operation, was commanded by Brigadier Mirko Norac. The Croatian Army Karlovac Corps composed of 15,000 troops, commanded by Major General Miljenko Crnjac, executed the Storm 2 plan. The Croatian Army Zagreb Corps of 30,000 troops, assigned the Storm 1 plan, was commanded by Major General Ivan Basarac. The Croatian Army Bjelovar Corps was commanded by Major General Luka Džanko.

Operation Storm began at dawn on 4 August 1995 and was declared complete on the evening of 7 August. The operation itself followed an unsuccessful United Nations peacekeeping mission and diplomatic effort to settle the conflict. On 4 August, coordinated attacks were executed by the Croatian Air Force with strikes aimed at disrupting Serbian army command, control, and communications. U.N. peacekeepers were notified three hours in advance of the attack by Tudjman's chief of staff to prevent civilian loss of life.

Operation Storm was a strategic victory in the Bosnian War, effectively ending the Serbian siege of Bihać and placing the Croatian Army, Croatian Defence Council, and the Army of Bosnia and Herzegovina in a position to change the military balance of power in Bosnia and Herzegovina. 
The Croatians quickly occupied Knin, the Serbian administrative headquarters. In anticipation of the Croatian takeover, Milošević ordered that in the event of Croatian military action, the civilian population should leave and head to Serbia. Close to 200,000 Serbs followed his directive. Serbian political leaders believed that a mass exodus of civilians would be described as a sign of violation of international law (Marijan 2010, pp. 160-169).

Operation Storm had a tremendous impact on the war in Bosnia, especially when the city of Bihać was liberated and the Serbian army was defeated. An exhausted, traumatized and famished 160,000 people in the city of Bihać welcomed their Croatian liberators. Storm was the last major battle of the Croatian War of Independence, and a major factor in the outcome of the Bosnian War. It was a decisive victory for the Croatian Army which attacked across a 390-mile front against the Serbian Army. The battle was launched to restore Croatian control of 4,000 square miles of their own territory, representing $18.4 \%$ of Croatia.

Čutura concludes:

Operation Storm was well planned. Moving tanks over the Dinara mountain chain, and their descent into the city of Knin represents the height of the art of modern warfare. Nowhere in battle at any point in military history have tanks emerged from a direction from which they were not expected, as occurred here. Operation Storm is currently being studied at military academies around the world, including the prestigious West Point.

As U.S. General James Mattis told the Croatian Minister of Defense at the Pentagon in 2018, "Storm is an operation that is studied in the U.S. military to show that a well-led, well-trained force with good political guidance can change the course of history. We have great respect for our friend and ally. Croatia is a small country, but, as we say, it bats above its weight, fights above its weight" (Mattis July 12, 2017; Vukić 2017).

General Rakić proudly declares:

The front line of Operation Storm was 397 miles long. It covered 425 square miles of occupied Croatian territory. The area was completely liberated by the Croatian Army in four days. There were two fundamental military goals. One was to reach the Knin Fortress and the other was to liberate the city of Bihać. Both were accomplished in record time.

Historian Nazor concludes:

Storm should not simply be seen as a military operation that liberated most of Croatia, but also as an operation that had a humanitarian character, since it saved the inhabitants of Bihać from almost certain genocide. The operation allowed the international community to save its honor after the disasters of Srebrenica and Prijedor when the U.N. forces stood by as thousands of civilians were massacred. Had the Serb forces entered Bihać, genocide 
on a far greater scale than Srebrenica would have occurred. Thanks to Operation Storm, and the three battles that followed it, the Serbian army was defeated and the conditions for the peace process to begin were finally established. The Dayton Agreement, signed in the U.S. and confirmed in Paris, was the result of a peace negotiation that ended the war. Unfortunately, one of the conditions of the Dayton Agreement was to turn over $49 \%$ of Bosnian territory to the Serbs.

Galbraith's considered judgment is that:

Operation Storm was the turning point in the wars of the former Yugoslavia, a turning point for the Croatian war which had begun in 1991, and for the war in Bosnia. It represented a decisive defeat for the Serbian side in the conflict, the side that had initiated it and as a result it led, within a few months, to the two peace agreements that ended the war, that is to say, the Erdut Agreement, which ended the war in Croatia and brought about the peaceful reintegration of the last bit of Serb-held territory in Eastern Slavonia, including Vukovar, and it led to the Dayton Peace Agreement, which ended the war in Bosnia.

According to Dr. Lang:

When the Croatian army liberated Bihać, I went to the city that same day. The international forces were completely confused and did not know what to do. Not a single incident occurred at the Knin Hospital after the entry of the Croatian Army, unlike the Vukovar Hospital, which was completely devastated by the Serbian Army and its patients liquidated in mass murder in Ovćara field.

Hague Tribunal Correspondent Visnja Starešina explains:

The majority of the international diplomatic community welcomed Operation Storm, recognizing it as the single solution to ending the war in Bosnia and Herzegovina. However, standing opposed it, were British diplomats and crown-related countries. Our diplomats and journalists were congratulated in Geneva. Even the staff of the Hague Tribunal toasted Operation Storm's start and successful completion with champagne (in interview August 2013).

Zuzul reminds us:

Had Operation Storm not been carried out, more than 40,000 people would have been killed in the genocide. U.N. forces wouldn't have done anything to prevent it. Genocide occurred in Rwanda, then in Srebrenica, and all that the U.N. did was to stand by and watch silently. The world has been incapable of addressing genocide. Operation Storm is the first military intervention in the history of mankind that has prevented genocide. 
General Dudaković agrees:

The value of the Dayton Agreement was that the killing and the terrible war were stopped. Operation Storm defeated the Serbian Army. Storm liberated Western Bosnia and Herzegovina. Unfortunately, however, the Republic of Serbia was created by the Dayton Agreement. This Republic was built on ethnic cleansing, terrible war crimes, and criminals convicted by the International Hague Tribunal.

Historian Kovacević complains that

Unfortunately, by the Dayton Agreement, Bosnia and Herzegovina was divided, giving $51 \%$ of the territory to Bosnian Muslims and Croatians, and $49 \%$ of the territory to Bosnian Serbs.

Galbraith responds to the criticism:

For all the criticism that's been made of Dayton, it was never intended as a roadmap for the organization of a country. It was intended as a means of ending a war, and measured by that standard, it has been a success.

Tudjman adds:

After the Dayton Agreement, 100,000 Serbs voluntarily left Sarajevo: 27,000 left Croatia escorted by the American ambassador, and between 50,000 and 80,000 left the eastern part of Croatia, when they realized that these areas would not become part of Greater Serbia.

Dudaković expresses regret:

I am sorry that we did not liberate Banja Luka. Splitting Bosnia and Herzegovina in half created an unresolvable political crisis. That is why we now have a power struggle with no possibility of agreement.

In a deeply revealing interview almost twenty-five years after the war, Galbraith states:

A defeat in Banja Luka would be a decisive defeat of a fascist Bosnian Serb regime that had engaged in genocide and mass murder. In short, there would be no Dayton. There would be no division of Bosnia. There would be the decisive defeat of the murderous and fascist side. And it was a difficult call. And in the end, because it was a difficult call, Holbrooke and I agreed that we would stay with the instructions we had. So, we went and told Tudjman not to go ahead, not to take Banja Luka. For years later, even to this day, I wonder whether that was the right decision. 


\section{Conclusions}

As Dr. Lang explains:

I was a humanitarian advisor to President Tudjman's government. Tudjman showed an extraordinary degree of intelligence and care. He appointed Hebrang as health minister, Granić as minister for refugees and displaced persons, and Kostolić as minister for prisoners of war and missing persons. No government in history has taken such proactive measures to address these concerns. If we wrote a book about the humanitarian dimension of modern warfare in 1996, no one in Croatia would have been charged with war crimes. Croatia would be at the center of the world's attention for doing good (in interview September 2013).

Čutura argues that:

The Croatian army did what the international community should have done. The international community and the U.N. did not do their job in protecting the civilian population, which was their primary task. Perhaps we shamed them and that is why our Croatian generals faced charges from the Hague International Tribunal (in interview August 2013).

According to Dr. Lang:

Operation Storm was a world-class military operation. It is important to say that the idea of preventing the war crime of genocide came from Croatia. Thanks to this, there is a permanent counselor for the prevention of genocide at the United Nations today. Conceptually and practically this idea comes from the Croatian military defense strategy of President Franjo Tudjman, who was the first to apply the principle of anticipating and confronting genocidal threat in the world. This Croatian contribution to the security of the world is amazing.

Jakob Bienenfeld argues that unlike questionable behavior in World War II, Croatia was extremely cognizant of its moral responsibility toward minorities. In fact,

Gojko Šušak, Minister of Defense of the Republic of Croatia, received recognition from the international Jewish organization JOIN. Generals Praljak, Gotovina and Tuta played an enormous role in the protection of Jews. It is a historical truth that needs to be repeated thousands of times because the Croatian people have shown that when they have their own state, the government has adopted very high standards in relation to minorities and respecting human rights (in interview September 2013). 
Academician Josip Pecarić, Professor of Mathematics, voices a position held by most Croatians:

As a reward for saving 160,000 people in Bihać, for bringing peace to Bosnia and Herzegovina, for ending the war, world powers brought charges against Croatian Generals Ante Gotovina and Mladen Markać, falsely accusing them of war crimes. Initially, the verdict of the Hague Tribunal was a lengthy sentence. This is the only case in human history in which people who defend their homes, save others, end violent occupations, fight against terrorists, and bring about conditions for a peaceful resolution of a conflict, are punished for it. Thank goodness, that outrageous verdict was overturned in 2015 and our generals were fully exonerated.

Hague Tribunal Correspondent Starešina argues that

The Hague Tribunal focused their accusations on General Gotovina who symbolized the new Croatian army. Built to Western standards--efficient, disciplined, pro-active--the Croatian Army was victorious over the Yugoslav Army in all combat operations. The Hague Tribunal appeared to use General Gotovina as a means to condemn the newly independent Croatian state.

In February 2015, at the conclusion of the Croatia-Serbia genocide case, 20 years after the end of the war, the International Court of Justice in the Hague dismissed a Serbian lawsuit which alleged that Operation Storm constituted genocide (BBC News 2015), ruling that Croatia did not have the specific intent to exterminate the country's Serb minority (International Court of Justice 2015, pp. 4, 141, 142). The court also found that the Croatian Army left accessible escape routes for civilians (International Court of Justice 2015, pp. 131, 139).

Hague Tribunal Correspondent Starešina notes:

Over the course of the five-year-long war, the progressive forces in the world sought ways to halt Serbian aggression, to end the project of Greater Serbia rooted in ethnic cleansing and genocide. Operation Storm proved that the Serbian war machine could be stopped. It was difficult to even imagine that Operation Storm's commanders would be forced to face the International Tribunal in The Hague from the accused's bench. In charging them, the Court failed to make the essential distinction between the aggressor, a war criminal, and the defendant-victim of the crime lawfully engaged in self-defense. It failed even to charge the Serbian generals who led an aggressive war against Croatia and Bosnia and Herzegovina. In the end, finally in 2015 , justice prevailed. The Croatian generals were exonerated. In March of 2019, 24 years after the fact, a U.N. appeals court upheld the genocide conviction of Radovan Karadžić, the former leader of the Bosnian Serbs, and increased his sentence to life for his role in Srebrenica.

Operation Storm, the largest European land battle since World War II was the crown jewel of the Croatian Homeland War. It demonstrated the extraordinary organizational, tactical, and strategic 
brilliance of the political and military leadership, who married science and improvisation. Croatian soldiers and officers showed enormous courage and determination. Their heroic efforts brought Serbia to its knees, which President Bill Clinton felt was a pre-condition for the Serbs agreeing to come to the peace table. Colonel Andrew Leslie, who commanded the United Nations Confidence Restoration Operation in Croatia in the Knin area assessed Operation Storm as a textbook operation that would have "scored an A-plus" by NATO standards (Dunigan 2011, p. 194).

In deeply moving words drawing on Shakespeare, Dr. Lang sums up his sense of the historical significance of Operation Storm:

The Croatians have enormous humility, but they should tell their children of their great victory, their triumph over evil. From this day to the ending of the world, Croatian soldiers "shall be remembered, this noble few, this band of brothers."

Parliamentarian Miroslav Tudjman, son of President Franjo Tudjman, states

As President Franjo Tudjman so aptly put it at the completion of Operation Storm: "On this day, we can say that Croatia stopped bearing its historical cross. This is not simply about the liberation of territory, but the creation of a foundation for a free and independent Croatia for centuries to come."

In light of increasing instability in the Western Balkans, there is broad support for minimizing Russian influence in the region, strengthening ties to trusted allies, and bringing together seasoned diplomatic, political and military experts to address threats to peace in the region and point a direction for democratic foreign policy initiatives.

\section{References}

Alasuutari, Pertti (2010). The Rise and Relevance of Qualitative Research. International Journal of Social Research Methodology. 13 (2): 139-155. https://doi.org/10.1080/13645570902966056

Armatta, Judith (2010). Twilight of impunity: The war crimes trial of Slobodan Milosevic. Durham, North Carolina: Duke University Press. https://doi.org/10.1215/9780822391791

Banac, Ivo (1988). With Stalin Against Tito: Cominformist Splits in Yugoslav Communism. Cornell University Press, p. 4; ISBN 0-8014-2186-1. https://doi.org/10.7591/9781501720833

BBC News, UN Court Dismisses Croatia and Serbia Genocide Claims. BBC News. London, England. 3 February 2015.

Beljo, A. (ed.) (1998) Greater Serbia: From ideology to aggression. Zagreb: Croatian Information Centre. Available at http://www.hic.hr/books/greatserbia/index.htm [Accessed 30 April 2020] 
Beljo, A. (1995). Yu-genocide: Bleiburg, death marches, UDBA (Yugoslav Secret Police). Toronto: Northern Tribune Publishing.

Beljo, A. (1985). Yugoslavia genocide: A documented analysis. Toronto: Northern Tribune Publishing.

Bethlehem, D. and Weller, M. (1997). The Yugoslav crisis in international law. Cambridge: Cambridge University Press.

Bosworth, Richard J.B. (2005). Mussolini's Italy. New Work: Allen Lane.

Central Intelligence Agency, Office of Russian and European Analysis (2002). Balkan battlegrounds: $A$ military history of the Yugoslav conflict, 1990-1995. Washington, D.C.: Central Intelligence Agency. OCLC 50396958.

Charlton, Thomas L.; Myers, Lois E.; Sharpless, Rebecca (Eds.) (2007). History of oral history: Foundations and methodology. Lanham, MD: Altamira Press.

Cohen, P. (1992). The U.S. Role in Catalyzing and Sustaining Serbian Aggression, Report to Clinton-Gore Transition Team, [online] December 17, $1992 . \quad$ Available at: http://www.siliconinvestor.com/readmsgs.aspx?subjectid=26815\&msgnum=3655\&batchsize $=10$ \&bat chtype=Next [Accessed 20 August 2020].

Cohen, Philip J. and Riesman, David (1996). Serbia's secret war: Propaganda and the deceit of history. Texas A\&M University Press.

Croatian Viewpoint (2008). 80th Anniversary of Serbian Assassination of Croatian MPs in Belgrade. Available at: http://croatianviewpoint.com/HousingFrameOne.

php?ShowThisPage=AssassinationOfCroatianMPsIn1928 [Accessed 25 July 2020]

Deutschland Military Tribunal (1950). Trials of war criminals before the Nuernberg Military Tribunals under Control Council Law no. 10 : Nuernberg Oct. 1946 - April 1949 Vol. 11 The High Command case. The Hostage case. Case 12. US v. von Leeb. Case 7. US v. List. Washington, D.C.: United States Government Printing Office. OCLC 247746272.

Dunigan, Molly (2011). Victory for hire: Private security companies' impact on military effectiveness. Palo Alto, California: Stanford University Press. https://doi.org/10.1515/9780804777414

Epstein, J. (1973). Operation Keelhaul : The story of forced repatriation from 1944 to the present. Old Greenwich, Connecticut: Devin-Adair.

Frucht, Richard C. (2005). Eastern Europe: An Introduction to the People, Lands, and Culture. p. 429. ABCCLIO; ISBN 1-57607-800-0.

Galbraith, Peter W. (2006). Negotiating Peace in Croatia: A Personal Account of the Road to Erdut. In Brad K. Blitz (ed.). War and change in the Balkans: Nationalism, conflict and cooperation. Cambridge, England: Cambridge University Press. ISBN 978-0-521-67773-8. 
Geiger, V. (2013). Human Losses of Croats in World War II and the Immediate Postwar Period Caused by the Chetniks (Yugoslav Army in the Fatherland) and the Partisans (People's Liberation Army and the Partisan Detachment of Yugoslavia/Yugoslav Army) and the Yugoslav Communist Authorities: Numerical Indicators. Review of Croatian History. Croatian Institute of History. 8 (1) pp. 77-121 [online] Available at: https://hrcak.srce.hr/103223?lang=en [Accessed 6 March 2020].

Glenny, Misha (2001). The Balkans: Nationalism, war, and the Great Powers 1804-1999, London: Penguin Books.

Grahek-Ravančić, M. (2006). Controversies about the Croatian Victims at Bleiburg. Review of Croatian History 2/1, pp. 27 - 46. Available at: http://docplayer.net/27204513-Controversies-about-thecroatianvictims-at-bleiburg-and-in-death-marches.html [Accessed: 1 June 2020].

Graubard, Stephen R. (1993). Exit from Communism. p. 153. New Brunswick: Transaction Publishers. ISBN 1-56000-694-3.

Hoare, Marko Attila (2010). The War of Yugoslav Succession. In Ramet, Sabrina P. (ed.).Central and Southeast European politics since 1989. Cambridge, England: Cambridge University Press. pp. 111-136. https://doi.org/10.1017/CBO9780511803185.010

Holbrooke, Richard (1999). To End a War. New York: Modern Library. ISBN 978-0-375-75360-2.

International Court of Justice (2015). Application of the Convention on the Prevention and Punishment of the Crime of Genocide (Croatia v. Serbia). The Hague: International Court of Justice. Archived from the original (PDF) on 12 July 2020.

Jareb, J. and Omrčanin, I. (1977-1978). The End of the Croatian Army at Bleiburg, Austria in May 1945 According to English Military Documents, Journal of Croatian Studies, Vol. XVIII-XIX. https://doi.org/10.5840/jcroatstud1977/7818/197

Jennings, Peter (1995). The Peacekeepers: How the U.N. Failed in Bosnia. 04/24/1995 [Accessed at: https://www.youtube.com/watch? $v=[2 J E r U Z R L R E \& t=5 s]$

Knez, Nikola (2019). Operation Storm. Texas \& Zagreb: iFilms LLC and The Croatian Film Institute.ISBN13-978-0-9793254-2-7 [Accessed at https://www.youtube.com/watch?v=yZcQAY48CJs\&feature=youtu.be and at https://www.youtube.com/watch?v=nKoUo8vzRnc] Approximately 157,000 views November 4, 2020.

Kulundžić, Zvonimir (1967). Atentat na Stjepana Radića. Zagreb: Stvarnost.

London Times (22 June 1928). The Belgrade Shootings—Croat Anger.

London Times (22 June 1928). Tragedy in Belgrade.

Marijan, Davor (2010). Storm. Zagreb, Croatia: Croatian Memorial Documentation Centre of the Homeland War of the Government of Croatia. ISBN 978-953-7439-25-5. 
Mattis, James (July 12, 2017). Remarks by Secretary Mattis in an Honor Cordon Welcoming Croatian Defense Minister Damir Krsticević to the Pentagon. U.S. Department of Defense. Available at: https://www.defense.gov/Newsroom/Transcripts/Transcript/ Article/1245735/remarks-by-secretarymattis-in-an-honor-cordon-welcoming-croatian-defense-minis/ [Accessed 8 January 2020].

Mazowiecki, Tadeusz (September 21, 1995). A Letter of Resignation. The New York Review of Books [Accessed on 8 October 2020 at: https://www.nybooks.com/articles/1995/09/21/a-letter-ofresignation/

McClellan, Dorothy and Knez, Nikola (2016). Prosecuting Rape, Sexual Enslavement, and Genocide in Time of War: Southeastern Europe 1991-1995, International Journal of Social Sciences, Vol. 5, No. 4, pp. 79-102. https://doi.org/10.20472/SS2016.5.4.005

McClellan, Dorothy and Knez, Nikola (2018). Post-World War II Forced Repatriations to Yugoslavia: Genocide's Legacy for Democratic Nation Building, International Journal of Social Sciences, Vol. VII, No. 2 pp. 62-91. https://doi.org/10.20472/SS2018.7.2.004

Meštrović, Stjepan Gabriel (1996). Genocide after emotion: The postemotional Balkan War. Routledge.

Mužić, Ivan (1991). Pavelić I Stepinac. Split: Logos.

National Archives, Holocaust Era Assets. RG 84: Yugoslavia. State Department and Foreign Affairs Records of the Foreign Service Posts [Accessed August 2020 at https://www.archives.gov/research/holocaust/finding-aid/civilian/rg-84-

yugoslavia.html\#: :text=King\%20Peter\%20and\%20his\%20ministers\%20went\%20to\%20London,Ger mans\%20were\%20communists\%20led\%20by\%20partisan\%20leader\%20Tito.]

The New York Times (6 May 1931). Einstein Accuses Yugoslavian Rulers in Savant's Murder.

Osser, Bernard and de Saint-Exupery, Patrick (September 21, 1995). The UN's Failure: An Interview with Tadeusz Mazowiecki translated from the French by Mark Romano. The New York Review of Books. [Accessed 8 October 2020 at https://www.nybooks.com/articles/1995/09/21/the-uns-failure-aninterview-with-tadeusz-

mazowiec/\#: :text=In\%201989\%20Tadeusz\%20Mazowiecki\%2C\%20a\%20founding\%20member\%2 0of,Commission\%20on\%20Human\%20Rights\%20in\%20the\%20Yugoslavian\%20conflict.]

Pavlowitch, Stevan . (2008). Hitler's new disorder: The Second World War in Yugoslavia. New York: Columbia University Press.

Pinter, Z. (2018). Roman Leljak--Istrazivac Koji je Zaduzio Hrvate [An Investigator Who Has Overwhelmed Croatians]. Croative Kultura i Politika [online] Available at: https://croative.net/roman-leljakistrazivaczaduzio-hrvate/ [Accessed 23 April 2020].

Prcela, J. and Guldescu, S. (eds.) (1970). Operation slaughterhouse: Eyewitness accounts of postwar massacres in Yugoslavia. Philadelphia: Dorrance. 
Prcela, J. and Guldescu, S. (eds.) (1995). Operation slaughterhouse: Eyewitness accounts of postwar massacres in Yugoslavia. Philadelphia: Dorrance.

Prcela, J. and Živić, D. (2001). Hrvatski holokaust [Croatian Holocaust] (in Croatian). Zagreb: Hrvatsko društvo političkih zatvorenika.

Ramet, Sabrina (2006). The three Yugoslavias: State-building and legitimation, 1918-2005. New York: Indiana University Press.

Redžić, Enver (2005). Bosnia and Herzegovina in the Second World War. Abingdon: Frank Cass. https://doi.org/10.4324/9780203309513

Reuters (19 August 1990). Roads Sealed as Yugoslav Unrest Mounts. The New York Times.

Roberts, Walter R. (1973). Tito, Mihailovic, and the Allies, 1941-1945. Rutgers University Press.

Rodogno, Davide (2006). Fascism's European empire: Italian occupation during the Second World War. Cambridge University Press.

Riley, Jonathon (2010). Decisive battles: From Yorktown to Operation Desert Storm. London, England:

Continuum International Publishing Group.

Starčević, Ante (1999). Izabrani politički spisi. Zagreb: Golden Marketing. (Collected Political Speeches).

Sudetić, Chuck (2 April 1991). Rebel Serbs Complicate Rift on Yugoslav Unity. The New York Times.

Sudetić, Chuck (26 June 1991). 2 Yugoslav States Vote Independence to Press Demands. The New York Times.

Sudetić, Chuck (29 June 1991). Conflict in Yugoslavia: 2 Yugoslav States Agree to Suspend

Secession Process. The New York Times.

Sudetić, Chuck (18 November 1991). Croats Concede Danube Town's Loss. The New York Times.

Sudetić, Chuck (3 January 1992). Yugoslav Factions Agree to U.N. Plan to Halt Civil War. The New York Times.

Šuljak, N. Dinko (1977). Croatia's Struggle for Independence: A Documentary History. Arcadia, California: Croatian Information Service.

Thomas, Nigel (2006). The Yugoslav Wars (1): Slovenia \& Croatia 1991-1995. Oxford, England: Osprey Publishing.

Thomas, Nigel; Mikulan, Krunoslav (1995). Axis Forces in Yugoslavia 1941-45: Men-at-arms. Illustrated by Darko Pavlovic. London: Osprey.

Tolstoy, N. (1986). The minister and the massacres. London: Century Hutchinson Ltd.

Tolstoy, N. (1977). Victims of Yalta: The secret betrayal. New York: Charles Scribner's Sons. 
Tomasevich, Jozo (1975). War and revolution in Yugoslavia, 1941-1945: The Chetniks. Stanford: Stanford University Press.

Tomasevich, Jozo (2001). War and revolution in Yugoslavia, 1941-1945 Occupation and collaboration. Stanford: Stanford University Press.

Vukić, Ina (2017). Serbia Forces Croatian Operation Storm into Intense False Memory Battlefield. Available at: https://projektvelebit.com/serbia-forces-croatian-operation-storm-into-intense-false-memorybattlefield/ [Accessed 6 January 2020].

Vukmanić, Miroslav (Ed.) (1995a). Stjepan Radić: Izabrani politicki Spisi. Opatija: Menora. (Selected Political Documents).

Vukmanić, Miroslav (Ed.) (1995b). Stjepan Radić: Izabrani politicki govori. Opatija: Menora. (Selected Political Speeches).

Vukmanić, Miroslav (Ed.) (1995c). Stjepan Radić: Izabrani politicki katekizam. Opatija: Menora. (Selected Political Catechism

Vukmanić, Miroslav (Ed.) (1995d). Stjepan Radić: Financijalna znanost. Opatija: Menora. (Contemporary Financial Science).

Yambrušić, Edward Slavko (2010). Peace at the price of justice and human dignity: Reflections on the Hague Tribunal \& judicialization of international conflicts. Zagreb: Croatian Cultural Council.

\section{Interviews}

Jakob Bienenfeld, President of Bet Israel Congregation of Croatia

Mario Bujanović, Member of the Croatian Defense Council in Bosnia and Herzegovina, city of Bihać

General Kresimir Ćosić, Deputy Minister of Defense

General Atif Dudaković, Commander, Fifth Corps of the Army of Bosnia and Herzegovina (ARBIH)

Peter Galbraith, United States Ambassador to Croatia 1993-1998

Emdzad Galijasević, Mayor of the city of Bihać

Dr. Roman Jurić, Member of the Croatian Defense Council in Bosnia and Herzegovina

Bernardo Jurlina, Croatian Minister of Minister of Labor, Social Welfare and Family, Special Croatian Envoy to Bihać

Mate Kovacević, Historian and Journalist

Dr. Slobodan Lang, Humanitarian Advisor to Croatian President Tudjman 1993-2000

Dr. Ivo Lucić, Historian and Former Chief of the Croatian Security Information Service

Dr. Davor Marijan, Historian and Veteran

Dr. Ante Marjanović, Member of the Croatian Defense Council in Bosnia and Herzegovina

Marijan Mihić, Member of the Croatian Defense Council in Bosnia and Herzegovina

Dr. Sc. Ante Nazor, Historian, Director of the Croatian Center of the Homeland War

Dr. Sc. Josip Pecarić, Academician, Professor of Mathematics 
General Rajko Rakić, Chief of Staff for General Ante Gotovina's Split Corps

Visnja Starešina, Hague Tribunal Correspondent

Dr. Sc. Miroslav Tudjman, Director of the Croatian Intelligence Agency 1993-2000, currently Member of Croatian Parliament, and son of former Croatian President Franjo Tudjman

Dr. Edward Slavko Yambrušić, International lawyer, fellow of the Center for the Research of International Law and International Relations of the Hague Academy

Miomir Zuzul, Croatian Ambassador to the United Nations 1993-1996 